Anais da Academia Brasileira de Ciências (2016) 88(2): 1055-1068

(Annals of the Brazilian Academy of Sciences)

Printed version ISSN 0001-3765 / Online version ISSN 1678-2690

http://dx.doi.org/10.1590/0001-3765201620150197

www.scielo.br/aabc

\title{
Extraction of bioactive compounds and free radical scavenging activity of purple basil (Ocimum basilicum L.) leaf extracts as affected by temperature and time
}

\author{
ALESSANDRA C. PEDRO ${ }^{1}$, FERNANDA MOREIRA ${ }^{2}$, DANIEL GRANATO ${ }^{1}$ and NEIVA D. ROSSO ${ }^{1,2}$ \\ ${ }^{1}$ Programa de Pós-Graduação em Ciência e Tecnologia de Alimentos, Universidade Estadual de \\ Ponta Grossa, Av. Carlos Cavalcanti, 4748, 84030-900 Ponta Grossa, PR, Brasil \\ ${ }^{2}$ Departamento de Química, Universidade Estadual de Ponta Grossa, Av. Carlos \\ Cavalcanti, 4748, 84030-900 Ponta Grossa, PR, Brasil \\ Manuscript received on March 19, 2015; accepted for publication on July 27, 2015
}

\begin{abstract}
In the current study, response surface methodology (RSM) was used to assess the effects of extraction time and temperature on the content of bioactive compounds and antioxidant activity of purple basil leaf (Ocimum basilicum L.) extracts. The stability of anthocyanins in relation to temperature, light and copigmentation was also studied. The highest anthocyanin content was $67.40 \mathrm{mg} / 100 \mathrm{~g}$ extracted at 30 ${ }^{\circ} \mathrm{C}$ and $60 \mathrm{~min}$. The degradation of anthocyanins with varying temperatures and in the presence of light followed a first-order kinetics and the activation energy was $44.95 \mathrm{~kJ} / \mathrm{mol}$. All the extracts exposed to light showed similar half-lives. The extracts protected from light, in the presence of copigments, showed an increase in half-life from $152.67 \mathrm{~h}$ for the control to 856.49 and $923.17 \mathrm{~h}$ for extract in the presence of gallic acid and phytic acid, respectively. These results clearly indicate that purple basil is a potential source of stable bioactive compounds.
\end{abstract}

Key words: anthocyanins, extraction, pigments, response surface methodology.

\section{INTRODUCTION}

Purple basil (Ocimum basilicum L.) is one of the species that belongs to a group of medicinal and aromatic plants of economic value worldwide, especially in Brazil where it is vastly used in traditional dishes, in the folk medicine, and various pharmaceutical applications (Rosas et al. 2004, Lee et al. 2005). The purple basil and belongs to the Lamiaceae family and its chemical composition is composed of an appreciable amount of phenolic compounds, especially flavonoids (Capecka et al. 2005, Carvalho-Filho et al. 2006). Nguyen et al. (2010) studied leaves of three cultivars of purple basil, namely Dark Opal, Sweet Thai, and Genovese, and observed that the basil treated with a higher potassium rate $(5.0 \mathrm{mM})$ resulted in an increase in the concentration of total phenolic compounds and antioxidant activity as compared to the basil treated with a lower potassium rate $(1.0 \mathrm{mM})$.

Correspondence to: Neiva Deliberali Rosso

E-mail: ndrosso@uepg.br 
Flavonoids are the major class of phenolic compounds and include the pigments called anthocyanins which are responsible for the color of many plants (Holton and Cornish 1995, Wu and Prior 2005, EscribanoBailón et al. 2004). Phippen and Simon (1998) studied different varieties of basil and found that the yield of anthocyanins ranged from 6.49 to $18.78 \mathrm{mg} / 100 \mathrm{~g}$ wet basis. These authors identified a total of fourteen acylated and glycosylated anthocyanins. Anthocyanins found in high concentrations in purple basil are: cyanidin based $p$-coumaryl and malonyl acids; cyanidin based $p$-coumaryl acid; cyanidin based $p$-coumaryl acid; peonidin 3-( $p$-coumaryl glucoside)-5-glucoside; cyanidin based $p$-coumaryl and malonyl acids.

Studies have shown that anthocyanins extracted from different botanical sources present beneficial health effects on humans, such as the reduction of inflammatory, circulatory, and coronary diseases (Bettini et al. 1985, Vincieri et al. 1992, Waterhouse 1995), in vitro anti-cancer properties (Lee et al. 2013), protection of neuronal cells (Pascual-Teresa 2014), in vitro and in vivo antioxidant properties (Kim et al. 2014, Szymanowska et al. 2015), and lipid-lowering effects (Zawistowski et al. 2009), anti-inflammatory and antimicrobial (Usman et al. 2013). Anthocyanin-rich extracts from purple potatoes, Solanum tuberosum L. cv Vitelotte noire (Solanaceae) had been shown to present anti-proliferative activity against the colon cancer cells Caco-2, SW48 and MCF7, MDA-MB-231 breast cancer cells, antimicrobial activity against Bacillus cereus, Escherichia coli and Pseudomonas aeruginosa and antioxidant activity after in vitro simulated gastrointestinal digestion (Ombra et al. 2015). As anthocyanins can be used as colorants in the food industry in replacement to synthetic dyes (Bridle and Timberlake 1997, Patil et al. 2009, Nontasan et al. 2012), there is a need to study new sources of such compounds and to assess their stability toward $\mathrm{pH}$, light, temperature, oxygen, enzymes, metalic ions, and copigments (Heredia et al. 1998).

The solvents most commonly used in anthocyanin extraction are methanol, ethanol, water acidified with acetic acid and ethanol added with hydrochloric acid (Shao et al. 2014, Phetpornpaisan et al. 2014, Pereira-Caro et al. 2013, Francis 1989). However, extraction procedures using ethanol and organic acids are desirable from a public health and industrial perspectives because they are not as toxic as methanol and hydrochloric acid (Escribano-Bailón et al. 2004, Pedro et al. 2016). Factors such as the type and volume of solvent, temperature and extraction time have a significant influence on the extraction of bioactive compounds from different matrices, so the use of mathematical models that describe accurately the isolated and combined effects of different factors (i.e., time, temperature, solvent volume) seems to be a most promising approach to obtain a functional extract from purple basil (Shao et al. 2014). In this sense, response surface methodology (RSM) can be used to assess the effects of different experimental factors (independent variables, i.e., time and temperature of extraction) on the content of chemical markers and bioactivity of plant extracts as they are the main contributors to the extraction and stability of bioactive compounds (Saha et al. 2011, Zhang et al. 2013, Granato et al. 2014a, Uddin et al. 2015, O'Shea et al. 2015).

Still there is a clear lack of studies regarding the evaluation of the effects of the main factors that influence the extraction of bioactive compounds from purple basil, and the evaluation of the stability of anthocyanins toward temperature, light and copigmentation. Based on this fact and taking into account the importance of new sources of natural colorants that can be applied in pharmaceutical, medical and food products, the objective of this study were to evaluate the effect of time and temperature on the extraction of bioactive compounds (total flavonoids, total phenolic content, and anthocyanins) and antioxidant activity of purple basil leaves using response surface methodology, and to evaluate the stability of anthocyanins toward temperature, light and copigmentation. 


\section{MATERIALS AND METHODS}

\section{CHEMICALS}

Gallic acid, 2,2-diphenyl-1-picrylhydrazyl (DPPH), Folin-Ciocalteau's phenol reagent, phytic acid (dipotassium salt) were acquired from Sigma Aldrich (St. Louis, USA). Ethyl alcohol (UV/HPLC grade, Vetec, São Paulo, Brazil), monohydrate citric acid (Reagen, Curitiba, Brazil), $\mathrm{HCl}, \mathrm{Na}_{2} \mathrm{CO}_{3}, \mathrm{KOH}$ and $\mathrm{KCl}$ (Merck, Germany) were of analytical grade. The solutions were prepared using ultrapure water (Millipore).

PREPARATION OF SAMPLES

Purple basil (Ocimum basilicum L.) samples were acquired in Ponta Grossa, PR, Brazil. The leaves were washed with distilled water, crushed and stored in low-density polyethylene sealed containers and protected from light, at $8^{\circ} \mathrm{C}$.

EXPERIMENTAL DESIGN AND EXTRACTION OF BIOACTIVE COMPOUNDS

A $2^{2}$ factorial design (two factors and two levels coded as +1 and -1) added with a central point was employed assess the effects of extraction time and temperature on the content of bioactive compounds and antioxidant activity of the purple basil extracts. The factors (independent variables) were extraction time $(20,40$ and $60 \mathrm{~min})$ and temperature $\left(10,20\right.$ and $\left.30^{\circ} \mathrm{C}\right)$, assuming $-1,0$, and +1 as coded values (Table I).

TABLE I

Total phenolic content, flavonoids, anthocyanins and in vitro antioxidant capacity of Ocimum basilicum L. leaf extracts obtained with different temperature and extraction times.

\begin{tabular}{cccccc}
\hline Temperature $\left({ }^{\circ} \mathrm{C}\right)$ & Time $(\mathrm{min})$ & $\begin{array}{c}\text { Total anthocyanins } \\
(\mathrm{mg} / 100 \mathrm{~g})\end{array}$ & $\begin{array}{c}\text { Total flavonoids } \\
(\mathrm{mg} / 100 \mathrm{~g})\end{array}$ & $\begin{array}{c}\text { Total phenolic content } \\
(\mathrm{mg} / 100 \mathrm{~g})\end{array}$ & $\begin{array}{c}\text { DPPH }(\% \\
\text { inhibition })\end{array}$ \\
\hline $10(-1)$ & $20(-1)$ & $21.81^{\mathrm{e}} \pm 0.28$ & $40.49^{\mathrm{d}} \pm 0.20$ & $272.54^{\mathrm{d}} \pm 0.68$ & $43.00^{\mathrm{d}} \pm 0.28$ \\
$10(-1)$ & $60(+1)$ & $36.85^{\mathrm{d}} \pm 0.04$ & $58.66^{\mathrm{c}} \pm 2.88$ & $404.71^{\mathrm{c}} \pm 0.69$ & $54.11^{\mathrm{c}} \pm 0.64$ \\
$30(+1)$ & $20(-1)$ & $47.10^{\mathrm{c}} \pm 0.50$ & $74.85^{\mathrm{b}} \pm 5.42$ & $464.30^{\mathrm{bc}} \pm 33.44$ & $66.99^{\mathrm{b}} \pm 1.79$ \\
$30(+1)$ & $60(+1)$ & $64.70^{\mathrm{a}} \pm 1.04$ & $106.23^{\mathrm{a}} \pm 10.38$ & $688.22^{\mathrm{a}} \pm 53.85$ & $77.21^{\mathrm{a}} \pm 0.47$ \\
$20(0)$ & $40(0)$ & $52.48^{\mathrm{b}} \pm 1.68$ & $79.81^{\mathrm{b}} \pm 2.83$ & $508.43^{\mathrm{b}} \pm 16.98$ & $69.43^{\mathrm{b}} \pm 3.41$ \\
\hline$p$-value (Bartlett test) & 0.15 & 0.17 & 0.03 & 0.21 \\
$p$-value (ANOVA/Welch) & $<0.0001$ & 0.0001 & $<0.0001$ & $<0.0001$ \\
\hline
\end{tabular}

Values are expressed as means \pm standard deviation $(n=3)$; ${ }^{2}$ Probability values obtained by the Bartlett test for homogeneity of variances; ${ }^{b}$ Probability values obtained by one-way analysis of variances (homoscedastic data) or Welch-ANOVA (heteroscedastic data). Different letters in the same column represent statistically different results according to the Fisher LSD test $(p \leq 0.05)$.

The response variables were: total anthocyanins, flavonoids, total phenolic content and in vitro antioxidant activity toward the DPPH radical. As the temperature is one of the most important factors affecting the stability of anthocyanins in natural extracts, in the current work we used only a range between 10 and 30 ${ }^{\circ} \mathrm{C}$. All experiments were performed in triplicate, including the extraction procedure.

The bioactive compounds were extracted from the purple basil according to the procedures described by Lees and Francis (1972), with some modifications. For that purpose, $1 \mathrm{~g}$ of leaf was macerated and added to a mixture of ethanol and citric acid $1.0 \mathrm{~mol} / \mathrm{L}(\mathrm{v}=10 \mathrm{~mL} ; 80: 20 \mathrm{v} / \mathrm{v})$ and the extraction was carried out according to the experimental design in a thermostated cell, protected from light, under constant stirring. Then, the content was qualitatively filtered (Whatman \#1 paper) and the residue and filter paper were 
washed until a volume of $25 \mathrm{~mL}$ was achieved. The extracts were stored at $-20{ }^{\circ} \mathrm{C}$, for fifteen days, until analysis.

TOTAL ANTHOCYANINS, FLAVONOIDS AND TOTAL PHENOLIC CONTENT

Total content of anthocyanins $(\lambda=535 \mathrm{~nm})$ and flavonoids $(\lambda=374 \mathrm{~nm})$ from the purple basil were quantified by UV-Vis spectrophotometry (Shimadzu UV-1800) using Equations 1 and 2, respectively and were expressed as mg cyanidin-3-glucoside equivalents (CGE) per $100 \mathrm{~g}$ of fresh tissue and mg quercetin equivalents (CE) per $100 \mathrm{~g}$ of fresh tissue.

Total anthocyanins $(\mathrm{TA})=\frac{\mathrm{A}_{535 \mathrm{~nm}} \times \text { dilution factor }}{98.2}$

Total flavonoids $(\mathrm{TF})=\frac{\mathrm{A}_{374 \mathrm{~nm}} \mathrm{X} \text { dilution factor }}{76.6}$

The Folin-Ciocalteu assay (Singleton et al. 1999) was used to assess the total hydrophilic phenolic content of purple basil leaf extracts. Briefly, $3.0 \mathrm{~mL}$ of ultrapure water, $250 \mu \mathrm{L}$ of Folin-Ciocalteu reagent $0.2 \mathrm{~N}$ and $250 \mu \mathrm{L}$ of diluted purple basil leaf extract were added to a test tube and the solution was agitated for 5 min. Then, an aliquot of $250 \mu \mathrm{L}$ of a $10 \% \mathrm{Na}_{2} \mathrm{CO}_{3}$ solution (w/v) was added, and the volume was completed to $5.0 \mathrm{~mL}$ with ultrapure water. After $60 \mathrm{~min}$ reaction, the absorbance was registered at $\lambda=761 \mathrm{~nm}$ using a spectrophotometer (Shimadzu 1800, Japan). For quantification purposes, an analytical curve of gallic acid (10 to $\left.70 \mu \mathrm{mol} / \mathrm{L}, \mathrm{y}=0.01816 \mathrm{x}-0.01015 ; \mathrm{R}^{2}=0.9982\right)$ as constructed and the total phenolic content was estimated. Data were expressed as $\mathrm{mg}$ of gallic acid equivalents per $100 \mathrm{~g}$ of fresh tissue (mg GAE/100 g).

\section{DETERMINATION OF ANTIOXIDANT ACTIVITY}

The free radical scavenging activity toward DPPH radical was quantified according to a previously described method (Brand-Williams et al. 1995), with modifications. The reaction time was based on a kinetic assay of DPPH with different concentrations of the extracts. Briefly, an aliquot $(1.5 \mathrm{~mL})$ of an ethanolic solution of DPPH $\left(2.2316 \times 10^{-4} \mathrm{~mol} / \mathrm{L}\right), 200 \mu \mathrm{L}$ of sample, and $1.8 \mathrm{~mL}$ of ethyl alcohol were added to a test tube to a final volume of $3.5 \mathrm{~mL}$. After 60 min reaction at $25 \pm 1{ }^{\circ} \mathrm{C}$, the absorbance was registered at $\lambda=517 \mathrm{~nm}$ and the DPPH inhibition of purple basil extracts was calculated using Equation 3.

DPPH inhibition $(\%)=\frac{\left(\mathrm{A}_{517 \mathrm{~nm} \text { of control }}-\mathrm{A}_{517 \mathrm{~nm} \text { of sample }}\right) \times 100}{\mathrm{~A}_{517 \mathrm{~nm} \text { of control }}}$

\section{STABILITY STUDIES OF THE ANTHOCYANIN EXTRACT EFFECT OF TEMPERATURE, LIGHT AND COPIGMENTATION}

The anthocyanins extract was diluted with ultrapure water according to the Lambert-Beer' law (maximum absorbance of 1.0 at $\lambda=516 \mathrm{~nm}$ ) and the changes in $\mathrm{pH}$ was recorded using a previously calibrated $\mathrm{pH}$ meter (MICRONAL B-474). For that purpose, $8 \mathrm{~mL}$ of this solution were transferred into a capped test tube protected from light and then tubed were immersed in a water bath (Microquímica MQBTC 99-20) at different temperatures $\left(60,70,80\right.$ and $\left.90{ }^{\circ} \mathrm{C}\right)$. For each temperature, the absorbance was recorded at a maximum wavelength $(\lambda=516 \mathrm{~nm})$ on times $0,30,60,90,120,150$ and $180 \mathrm{~min}$. Using these data, the percentage of color degradation $(\% \mathrm{R})$, rate constant for anthocyanins degradation $(\mathrm{k})$, half-life time $\left(\mathrm{t}_{1 / 2}\right)$, 
and activation energy $\left(\mathrm{E}_{\mathrm{A}}\right)$ were calculated using Equations 4, 5, 6 and 7, respectively (Reyes and CisnerosZevallos 2007).

$\% \mathrm{R}=\left(\mathrm{A}_{\mathrm{t}} / \mathrm{A}_{0}\right) \times 100$

$\ln \left(\mathrm{A}_{\mathrm{t}} / \mathrm{A}_{0}\right)=-\mathrm{k} \times \mathrm{t}$

$\mathrm{t}_{1 / 2}=\ln 2 / \mathrm{k}$

$\ln \mathrm{k}=-\mathrm{E}_{\mathrm{A}} / \mathrm{RT}+\ln \mathrm{A}$

whereby: $\mathrm{A}_{\mathrm{t}}=$ final absorbance; $\mathrm{A}_{0}=$ initial absorbance; $\mathrm{R}=8,314462 \mathrm{~J} \mathrm{~K}^{-1} \mathrm{~mol}^{-1} ; \mathrm{T}=$ absolute temperature $(\mathrm{K})$.

The effect of light and copigmentation on the stability of anthocyanins was conducted according to the procedures described by Amr and Al-Tamimi (2007) and Awika (2008), with modifications. Three solutions of extract were prepared using a sodium citrate/citric acid buffer solution at $0.1 \mathrm{~mol} / \mathrm{L}$ and $\mathrm{pH} 3.6$. One of the solutions was considered the control (absence of copigments) and in the other phytic acid and gallic acid were added at a concentration of $7.5 \times 10^{-4} \mathrm{~mol} / \mathrm{L}$. Each solution was divided into three flasks with $15 \mathrm{~mL}$ each, covered with plastic wrap and exposed continuously to the direct light of a white fluorescent lamp $(20 \mathrm{~W})$ in a closed wooden chamber $\left(\mathrm{T}=32 \pm 2{ }^{\circ} \mathrm{C}\right)$. The absorbance was recorded every $60 \mathrm{~min}$ at $\lambda$ $=535 \mathrm{~nm}$ until a $50 \%$ decrease in the initial absorbance was achieved. The rate constant for degradation of anthocyanins $(\mathrm{k})$ and its half-life $\left(\mathrm{t}_{1 / 2}\right)$ (Reyes and Cisneros-Zevallos 2007) were calculated using Equations 5 and 6 , respectively.

\section{STATISTICAL ANALYSIS}

Results are expressed as means followed by the standard deviation $(n=3)$. Differences among the five treatments were highlighted by one-way analysis of variances and means were compared using the Fisher's least significant difference test (LSD) after checking the homoscedasticity by the Bartlett's test. When data were heteroscedastic, Welch analysis of variances was applied (Nunes et al. 2015) Linear regression analysis was carried out to assess, quantitatively, the correlation between responses. Probability values below 5\% were considered significant for inferential analysis (Granato et al. 2014a).

The effects of extraction time and temperature on the content of total phenolic content, flavonoids, anthocyanins, and antioxidant activity (DPPH assay) were assessed by means of the response surface methodology (Alvarez et al. 2015). For that purpose, the responses $[\mathrm{E}(\mathrm{y})]$ were described as a function of the extraction time $\left(\mathrm{x}_{1}\right)$, temperature $\left(\mathrm{x}_{2}\right)$, and their linear interaction $\left(\mathrm{x}_{1} \mathrm{x}_{2}\right)$ using Equation: $\mathrm{E}(\mathrm{y})=\beta_{\mathrm{o}}+\beta_{1} x_{1}$ $+\beta_{2} x_{2}+\beta_{12} x_{1} x_{2}$, whereby $\beta_{0}$ is a constant, and $\beta_{1}, \beta_{2}$ and $\beta_{12}$ are regression coefficients. When the regression coefficient was not significant $(p>0.10)$, it was removed from the initial model and experimental data were refitted to provide the final multiple regression model and to generate 2-dimensional contour plots for the responses (Rebouças et al. 2014). All analysis were performed using Action v. 2.8 (Statcamp, Brazil) and Statistica v. 7 (Statsoft, USA) software.

\section{RESULTS AND DISCUSSION}

\section{BIOACTIVE COMPOUNDS AND RSM MODELING}

The concentration of total anthocyanins, flavonoids, total phenolic compounds and in vitro free radical scavenging activity toward DPPH radical is shown in Table I. It is possible to observe that the time and 
temperature of extraction impacted significantly in all response variables $(p<0.0001)$. The Ocimum basilicum L. leaf extracts presented a high content of total phenolics $(272-688 \mathrm{mg} / 100 \mathrm{~g})$ in which about 14.49 to $16.12 \%$ are made of total flavonoids $(40.49-106.23 \mathrm{mg} / 100 \mathrm{~g})$. It is important to note that the content of anthocyanins ranged from 21.81 and $64.70 \mathrm{mg} / 100 \mathrm{~g}$, representing from 8.0 to $10.3 \%$ of the total phenolic content (w/w fresh tissue).

Higher contents $(p<0.05)$ of total anthocyanins, flavonoids, total phenolic content and antioxidant activity were obtained when the extraction temperature and time were higher $\left(\mathrm{t}=60 \mathrm{~min}\right.$ and $\left.\mathrm{T}=30{ }^{\circ} \mathrm{C}\right)$ and this was corroborated by means of inferential statistical analysis (ANOVA/Welch-ANOVA followed by Fisher's least significance difference test). When purple basis was extracted using $\mathrm{t}=40 \mathrm{~min}$ and $\mathrm{T}=$ $20^{\circ} \mathrm{C}$, high contents of bioactive compounds and antioxidant activity were also obtained, however, lower $(p<0.05)$ than those obtained with $\mathrm{t}=60 \mathrm{~min}$ and $\mathrm{T}=30^{\circ} \mathrm{C}$. On the other hand, when purple basil was extracted with using $\mathrm{T}=10^{\circ} \mathrm{C}$ and $\mathrm{t}=20 \mathrm{~min}$, the lowest values of all bioactive compounds and free radical scavenging activity were observed, indicating a poor extraction of antioxidant compounds.

After checking statistical differences among treatments, the main purpose of the current research work was to assess the quantitative effects of the response variables (extraction time and temperature) on the antioxidant compounds from purple basil leaves. For this purpose, multiple linear regression analysis based on the response surface methodology was used and results are shown in Table II and the contour plots generated using the experimental data are shown in Figure 1. Both extraction time and temperature were highly significant $(t$-value $=21.32$ and $34.70, p<0.001$, respectively) in the extraction of total anthocyanins and the model was deemed significant $\left(R^{2}=0.897\right.$ and adjusted $\left.R^{2}=0.872\right)$.

TABLE II

Regression coefficients obtained by multiple regression analysis (response surface methodology) to assess the effects of time and temperature of extraction of total anthocyanins, flavonoids, total phenolic content, and antioxidant activity of Ocimum basilicum L. leaf extracts.

\begin{tabular}{|c|c|c|c|c|c|c|}
\hline Parameters & $\begin{array}{c}\text { Regression } \\
\text { coefficient }\end{array}$ & Standard error & $t$-value & $p$-value & $\begin{array}{c}-95 \% \text { confidence } \\
\text { limit }\end{array}$ & $\begin{array}{c}+95 \% \text { confidence } \\
\text { limit }\end{array}$ \\
\hline \multicolumn{7}{|c|}{ Total anthocyanins } \\
\hline Mean & 2.418 & 1.131 & 2.138 & 0.076 & -0.349 & 5.185 \\
\hline (1)Temperature $\left({ }^{\circ} \mathrm{C}\right)$ & 1.328 & 0.038 & 34.697 & $<0.001$ & 1.234 & 1.422 \\
\hline (2)Time (min) & 0.408 & 0.019 & 21.315 & $<0.001$ & 0.361 & 0.455 \\
\hline $\mathrm{R}^{2}$ & 0.897 & & & & & \\
\hline Adjusted $\mathrm{R}^{2}$ & 0.872 & & & & & \\
\hline \multicolumn{7}{|c|}{ Total flavonoids } \\
\hline Mean & 31.753 & 3.988 & 7.961 & $<0.001$ & 21.994 & 41.513 \\
\hline (1)Temperature $\left({ }^{\circ} \mathrm{C}\right)$ & 0.925 & 0.246 & 3.758 & 0.009 & 0.322 & 1.527 \\
\hline 1 by 2 & 0.028 & 0.004 & 6.846 & $<0.001$ & 0.018 & 0.038 \\
\hline $\mathrm{R}^{2}$ & 0.916 & & & & & \\
\hline Adjusted $\mathrm{R}^{2}$ & 0.895 & & & & & \\
\hline \multicolumn{7}{|c|}{ Total phenolic content } \\
\hline Mean & 147.421 & 48.659 & 3.029 & 0.023 & 28.357 & 266.485 \\
\hline (1)Temperature $\left({ }^{\circ} \mathrm{C}\right)$ & 7.294 & 2.188 & 3.333 & 0.016 & 1.940 & 12.648 \\
\hline (2)Time (min) & 2.157 & 1.094 & 1.972 & 0.096 & -0.520 & 4.834 \\
\hline 1 by 2 & 0.115 & 0.048 & 2.344 & 0.057 & -0.005 & 0.234 \\
\hline $\mathrm{R}^{2}$ & 0.946 & & & & & \\
\hline Adjusted $\mathrm{R}^{2}$ & 0.923 & & & & & \\
\hline
\end{tabular}


TABLE II (continuation)

\begin{tabular}{ccccccc}
\hline Parameters & $\begin{array}{c}\text { Regression } \\
\text { coefficient }\end{array}$ & Standard error & $\boldsymbol{t}$-value & $\boldsymbol{p}$-value & $\begin{array}{c}\mathbf{- 9 5 \%} \text { confidence } \\
\text { limit }\end{array}$ & $\begin{array}{c}+95 \% \text { confidence } \\
\text { limit }\end{array}$ \\
\hline & & \multicolumn{7}{c}{ Free radical scavenging activity toward DPPH } & \\
Mean & 28.598 & 2.220 & 12.879 & $<0.001$ & 23.165 & 34.031 \\
(1)Temperature $\left({ }^{\circ} \mathrm{C}\right)$ & 1.177 & 0.075 & 15.663 & $<0.001$ & 0.993 & 1.361 \\
$(2)$ Time (min) & 0.266 & 0.037 & 7.094 & $<0.001$ & 0.175 & 0.358 \\
$\mathrm{R}^{2}$ & 0.865 & & & & & \\
Adjusted $\mathrm{R}^{2}$ & 0.831 & & & & & \\
\hline
\end{tabular}
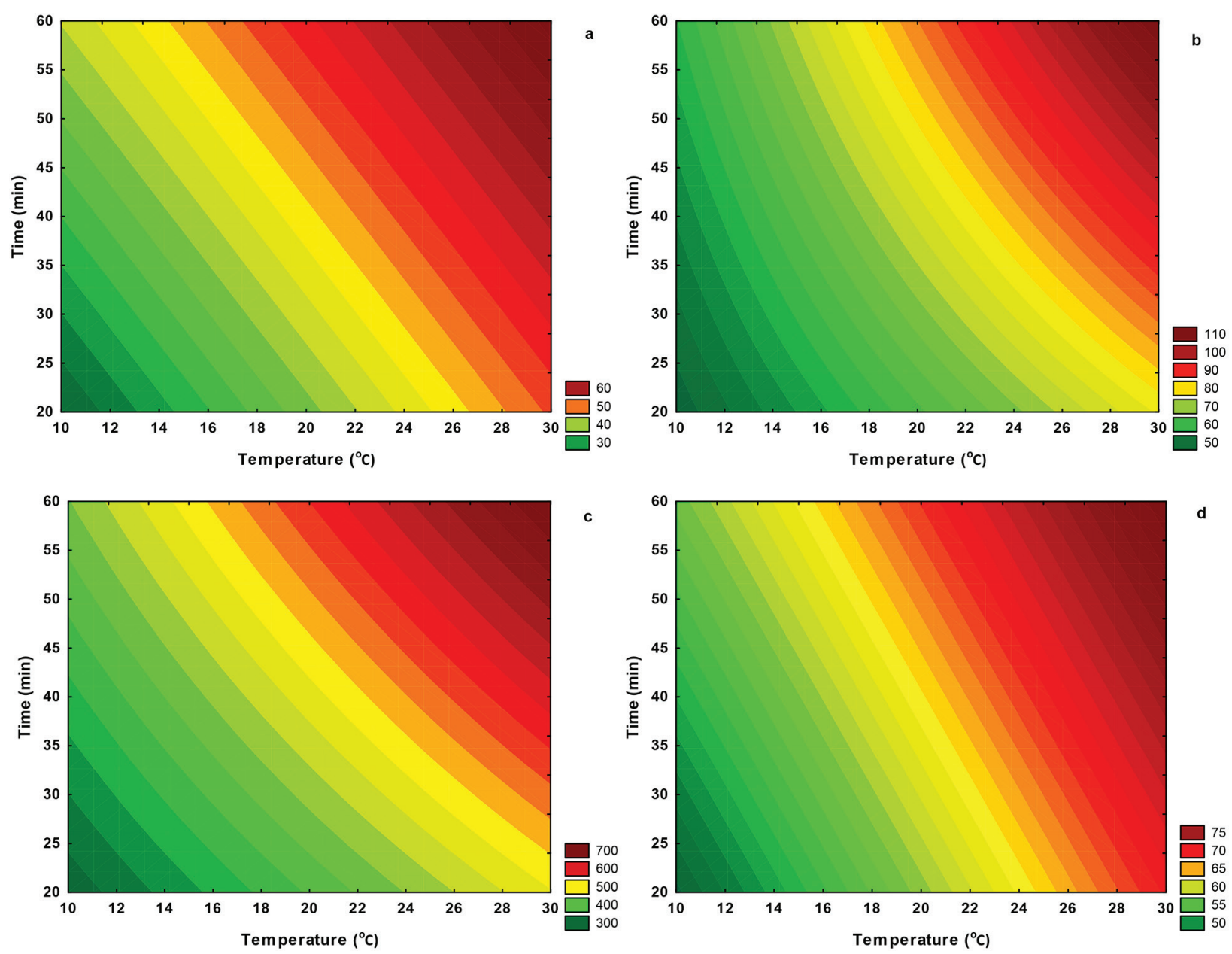

Figure 1 - Contour plots to project the experimental data obtained for the extraction of total anthocyanins (a), total flavonoids (b), total phenolic content (c), and free radical scavenging activity (d) of Ocimum basilicum L. extracts. All data are expressed as $\mathrm{mg} / 100 \mathrm{~g}$. For interpretation of the references to color in this figure legend, the reader is referred to the web version of this article.

For the total flavonoids content, the effect of temperature $(t$-value $=3.758, p=0.009)$ and the linear interaction between time and temperature $(t$-value $=6.846, p<0.001)$ were the parameters that influenced the response, while the effect of time $(t$-value $=1.409, p=0.208)$ was not important. This model also presented a high coefficient of determination $\left(R^{2}=0.916\right.$ and adjusted $\left.R^{2}=0.895\right)$, implying that more than $90 \%$ of data variability was explained by the multiple linear regression model (Bassani et al. 2014). 
The higher the extraction time ( $t$-value $=1.972, p=0.096)$ and, more importantly the temperature $(t$-value $=3.333, p=0.016)$, the higher the content of total phenolic compounds. The interaction between these two factors also influenced positively the extraction of phenolic compounds from purple basil ( $t$-value $=2.344, p=0.057)$. The regression model explained up to $95 \%$ of data variability, indicating the suitability of RSM in modeling the extraction of total phenolic content in the range studied.

The free radical scavenging activity toward DPPH radical was also modeled by means of RSM and results clearly indicated the statistical significance of extraction time $(t$-value $=7.094, p<0.001)$ and temperature $(t$-value $=15.663, p<0.001)$ on the response. Interestingly, the interaction of both independent variables did not affect significantly $(t$-value $=-0.293, p=0.780)$ the antioxidant activity of purple basil extracts under the conditions adopted in the current work. The proposed multiple regression model presented $\mathrm{R}^{2}=0.865$ and adjusted $\mathrm{R}^{2}=0.831$, indicating it was possible to model the effects of time and temperature on such a chemical response.

One of the most important advantages of using RSM is to provide useful regression equations that can be applied to predict certain responses based on pre-selected factors. In other words, if the equations generated are statistically significant ( $p$-value of regression coefficients are below the stipulated $\alpha$-value) and the equations can explain more than $70 \%$ of data variability $\left(\mathrm{R}^{2}>0.70\right)$, it is possible to assume the model can be used to predict the response on the basis of specific values of the factors (independent variables). In our case, all regression models generated presented $p<0.10$ and $\mathrm{R}^{2}>0.80$. So, if one considers the extraction of total anthocyanins conducted at $\mathrm{T}=27^{\circ} \mathrm{C}$ and $\mathrm{t}=47 \mathrm{~min}$, the mean theoretical value would be $57.46 \mathrm{mg} / 100 \mathrm{~g}$ (confidence interval at $\pm 95 \%=56.37-58.54 \mathrm{mg} / 100 \mathrm{~g}$ ). The same is applied to the other variables: if one wishes to have an idea of the experimental value to be obtained when the extraction of total flavonoids is conducted at $\mathrm{T}=18.8^{\circ} \mathrm{C}$ and $\mathrm{t}=36 \mathrm{~min}$, the mean concentration of flavonoids should be $68.15 \mathrm{mg} / 100 \mathrm{~g}$ and the confidence interval at $\pm 95 \%$ would be 64.21 and $72.08 \mathrm{mg} / 100 \mathrm{~g}$. Clearly, it would be more valid if the analysis goes back to the laboratory and perform the experiment under the simulated conditions ( $\mathrm{T}$ and $\mathrm{t}$ ) and compare the experimental and theoretical values. If both results are in agreement (relative standard error below 10\%), then the regression model can be regarded as significant and predictive (Granato et al. 2014b).

Similarly to what was observed in the current study, Bassani et al. (2014) used a $3^{2}$ design of experiment aimed to model the effects of extraction time $(5,7.5$, and $10 \mathrm{~min})$ and temperature $\left(60,75,90{ }^{\circ} \mathrm{C}\right)$ on the total content of phenolic compounds and total flavonoids content as well as on the antioxidant capacity (DPPH assay) of water-soluble extracts from roasted leaves of Ilex paraguariensis and authors obtained high $\mathrm{R}^{2}$ values: 0.989 (antioxidant activity), 0.997 (total phenolic content), and 0.999 (total flavonoids). Pedro et al. (2016) used a Box-Behnken design to assess the effects of temperature $\left(10-50^{\circ} \mathrm{C}\right)$, time $(20$ $80 \mathrm{~min})$, and solid-solvent ratio $(1: 15-1: 45 \mathrm{w} / \mathrm{v})$ on the extraction of total phenolic content, total flavonoids content, total anthocyanins, and in vitro antioxidant activity of extracts from Oryza sativa L. (black rice). Experimental data were subjected to RSM modeling and authors were able to identify the factors (alone and in combination) that affected the extraction of bioactive compounds and presented regression equations based on RSM to explain the results.

Using linear regression analysis, it was possible to analyze the correlation between the antioxidant activity toward DPPH radical and the total phenolic content (Figure 2a), flavonoids (Figure 2b), and total anthocyanins (Figure 2c). Not surprisingly, all correlations were highly significant $(p<0.05)$ from the statistical standpoint, showing the importance of such compounds in scavenging the free radicals in the 
reaction medium. The proposed equations can be used experimentally (inside the range of the study) to have an idea of the antioxidant activity toward DPPH radical in terms of the content of bioactive compounds. For example, if one wishes to estimate the antioxidant activity of a purple basil extract containing $350,87.50$, or $53.90 \mathrm{mg} / 100 \mathrm{~g}$ of total phenolic content, total flavonoids, and total anthocyanins, respectively using the exact extraction conditions employed in the current work, one would obtain, theoretically, 52.17, 70.50, and $69.85 \%$ of DPPH inhibition, respectively.
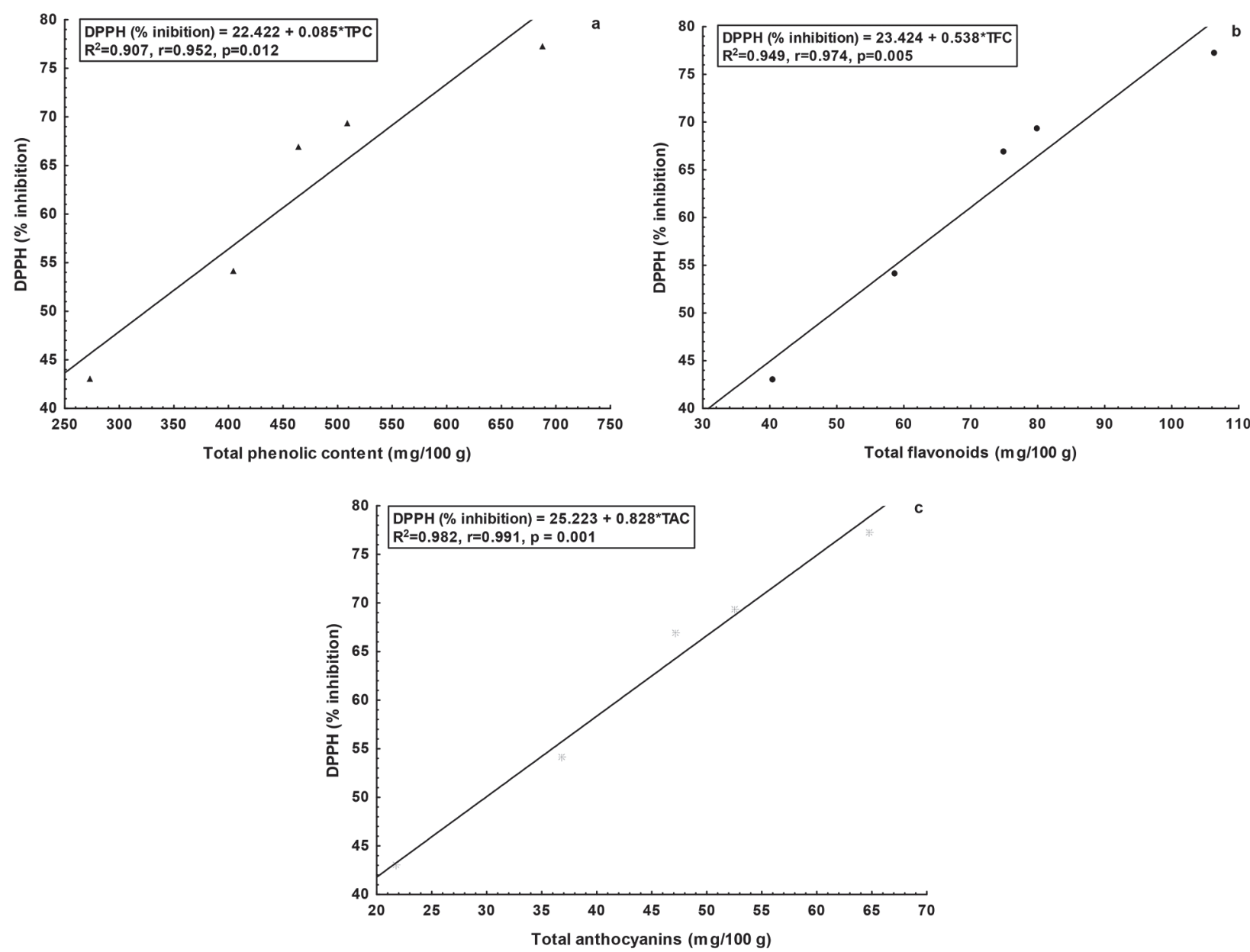

Figure 2 - Regression analysis based on the ordinary least-squares method between the free radical scavenging activity toward $\mathrm{DPPH}$ and the total content of phenolic compounds (a), flavonoids (b), and total anthocyanins (c). Note that TPC $=$ total phenolic content, $\mathrm{TFC}=$ total flavonoids content, and TAC $=$ total anthocyanins content.

The antioxidant activity of phenolic compounds in a food extract depends on the number and type of functional groups present in the aromatic ring, such as the hydroxyl groups and the position they occupy, either ortho or para, as well as the presence of other groups. The combination of the non-binding electron pair of the hydroxyl group with the PI system (л) of the aromatic ring strongly activates the ortho and para positions. Similarly, other functional groups, such as alkyl and methoxyl weakly activate the ortho and para positions by hiperconjugative effects. These groups favor electron delocalization and stabilize the phenoxyl radical formed on oxidation processes (Rice-Evans et al. 1996). 


\section{STABILITy STUdy OF PURPLE BASIL ANTHOCYANINS EFFECT OF TEMPERATURE}

From the study of the effect of temperature on the stability of anthocyanins extracted from purple basil, a linear behavior was observed, indicating that the thermal degradation followed first-order kinetics. Table III shows the degradation rate constant $(k)$, the half-life time $\left(\mathrm{t}_{1 / 2}\right)$ and color retention percentage $(\% \mathrm{R})$ of the anthocyanins as the temperature increased. These parameters show that the rate of degradation reaction increased when the temperature was raised as a function of exposure time. It is observed that the half-life decreased markedly according to the increase in temperature. Patras et al. (2010) suggested that foods rich in anthocyanins should be manufactured at low temperatures and be stored for reduced periods of time. This provides greater retention of color and stability to the pigment.

TABLE III

Effects of temperature on the degradation of anthocyanins as noted by the first-order rate constant $(k)$, half-life time $\left(t_{1 / 2}\right)$, and retention of color $(R)$.

\begin{tabular}{cccccc}
\hline Temperature $\left({ }^{\circ} \mathrm{C}\right)$ & $k\left(\mathrm{~h}^{-1}\right)$ & ${ }^{\mathrm{a}} \mathrm{R}^{2}$ & $\mathrm{t}_{1 / 2}(\mathrm{~h})$ & $\mathrm{R}(\%)$ & ${ }^{\mathrm{b}} p$-value \\
\hline 60 & 0.01288 & 0.9974 & 53.82 & 0.963 & $<0.0001$ \\
70 & 0.02261 & 0.9990 & 30.66 & 0.935 & 0.0226 \\
80 & 0.02515 & 0.9977 & 27.56 & 0.915 & $<0.0001$ \\
90 & 0.05466 & 0.9935 & 12.68 & 0.887 & 0.0006 \\
\hline${ }^{\mathrm{a}} \mathrm{R}^{2}=$ coefficient of determination; ${ }^{\mathrm{b}} p$-value = probability value obtained by analysis of variances.
\end{tabular}

The activation energy for the reaction of anthocyanins degradation was $44.95 \mathrm{~kJ} / \mathrm{mol}$. Mourtzinos et al. (2008) found that the activation energy was $54 \mathrm{~kJ} / \mathrm{mol}$ for anthocyanins extracted from Hibiscus sabdariffa L. According to Silva et al. (2010) excessive heating may promote the loss of anthocyanin color and cause the opening of the aromatic ring chalcones forming colorless compounds (Katsaboxakis et al. 1998, Heredia et al. 1998). Reduced values of activation energy suggest that the anthocyanin extract is susceptible to degradation when temperature is increased (Hou et al. 2013).

\section{EFFECT OF LIGHT AND COPIGMENTATION}

Table IV shows the rate constants and half-lives for reaction of anthocyanins degradation toward light in the purple basil with or without copigments. It was found that after 24 hours, all extracts exposed to light showed no significant difference in the half-life (control $-17.08 \mathrm{~h}$, phytic acid $-15.61 \mathrm{~h}$ and gallic acid - $17.20 \mathrm{~h}$ ). However, all extracts protected from light showed a remarkably higher half-life than the extracts exposed to light. Lima et al. (2005) observed that the anthocyanin extracts from purple cherry showed greater stability when protected from light. Bąkowska et al. (2003) found that the heating and UV irradiation affect negatively the stability of anthocyanins.

The half-life for the extracts protected from light in the presence of phytic and gallic acids was 923.17 and $856.49 \mathrm{~h}$, after 24 hours, respectively, whereas half-life of the control was $152.67 \mathrm{~h}$. The considerable increase in half-life of the extracts in the presence of phytic and gallic acids compared to the control shows the effect of cogpigmentation on the chemical stabilization of anthocyanins. Copigments have $p i$ electron and may link with the flavylium ion. This combination protects the anthocyanin molecule against nucleophilic attack by water and consequently increases its chemical stability (Mazza and Brouillard 1990).

The interaction of copigments with the anthocyanins gives the bathochromic effect (increase of the maximum absorbance) and hyperchromatic effect (shift of the peak wavelength) (Bąkowska et al. 2003). 
TABLE IV

Effects of light and copigments on the first-order rate constant $(k)$ and half-life time $\left(t_{1 / 2}\right)$ on the degradation of anthocyanins extracted from Ocimum basilicum $\mathrm{L}$. leaf.

\begin{tabular}{ccccc}
\hline Extract & $k\left(\mathrm{~h}^{-1}\right)$ & ${ }^{\mathrm{a}} \mathrm{R}^{2}$ & $\mathrm{t}_{1 / 2}(\mathrm{~h})$ & ${ }^{\mathrm{b}} p$-value \\
\hline Control (protected) & 0.00454 & 0.9998 & 152.67 & $<0.0001$ \\
Control (exposed) & 0.04058 & 0.9963 & 17.08 & $<0.0001$ \\
Phytic acid (protected) & 0.00075 & 0.9969 & 923.17 & $<0.0001$ \\
Phytic acid (exposed) & 0.0444 & 0.9977 & 15.61 & $<0.0001$ \\
Gallic acid (protected) & 0.00081 & 0.9985 & 856.49 & $<0.0001$ \\
Gallic acid (exposed) & 0.04029 & 0.9987 & 17.20 & $<0.0001$ \\
\hline
\end{tabular}

${ }^{a} \mathrm{R}^{2}=$ coefficient of determination; ${ }^{\mathrm{b}} p$-value = probability value obtained by analysis of variances.

The increase in half-life of anthocyanin extracts (protected from light) in the presence of copigments yielded a significant increase in the chemical stability of the extracts. Gauche et al. (2010) observed an increased half-life of anthocyanins from Cabernet Sauvignon grapes added with tannic and gallic acids as compared to the control. Gris et al. (2007) found that a solution containing anthocyanins extracted from Caberbet Sauvignon grapes in the presence of caffeic acid and absence of light presented an increased halflife compared to the control.

Some experimental parameters, such as solvent polarity, temperature, extraction time, and solvent: food matrix ratio are important to extract bioactive compounds from a certain source. The most commonly extraction solvents used are methanol and ethanol in acidic medium. Under these conditions the flavylium cation of anthocyanins (red color) is more stable. Strong acids can hydrolyze the structure of the molecule, while weak acids such as citric and tartaric acids are preferred (Strack and Wray 1989). Methanol is an efficient solvent for extraction of many bioactive compounds, however, its degree of toxicity should be considered, especially by food companies (Escribano-Bailón et al. 2004). Thus, considering the stability of anthocyanins in acidic medium and the toxicity of the solvent, ethanol in the presence of citric acid was used in the current work to extract antioxidant compounds from purple basil. The use of this solvent can facilitate the application of the extract in food products due to its low toxicity.

As a conclusion, RSM was shown to be a suitable statistical approach to model the effects of time and temperature on the extraction of bioactive compounds as well as antioxidant activity from purple basil leaf. As the anthocyanins extract was stable at moderate temperature, the application of such extract in food matrix may be advantageous over synthetic colorants. In this sense, further works should focus on the application of purple basil extracts in beverages and other foods and study their sensory properties and chemical stability during shelf life.

\section{ACKNOWLEDGMENTS}

Authors are grateful for the financial support provided by Coordenação de Aperfeiçoamento de Pessoal de Nível Superior/Programa de Apoio à Pós-Graduação (CAPES/PROAP) and Programa Nacional de Pós-Doutorado (CAPES/PNPD) (D. Granato) and to the support provided by Central de Laboratórios Multiusuários/Universidade Estadual de Ponta Grossa (CLABMU/UEPG).

\section{RESUMO}

No presente estudo, a metodologia de superfície de resposta (MSR) foi utilizada para avaliar o efeito de tempo e temperatura de extração no conteúdo de compostos bioativos e atividade antioxidante de extratos de folhas de manjericão 
roxo (Ocimum basilicum L.). A estabilidade das antocianinas relacionada à temperatura, luz e copigmentação também foi estudada. O maior conteúdo de antocianinas foi $64,70 \mathrm{mg} / 100 \mathrm{~g}$ a $30^{\circ} \mathrm{C}$ e $60 \mathrm{~min}$. A degradação das antocianinas com diferentes temperaturas e em presença de luz seguiu uma cinética de primeira ordem e a energia de ativação foi $44,95 \mathrm{~kJ} / \mathrm{mol}$. Todos os extratos expostos à luz apresentaram tempos de meia vida semelhantes. Enquanto que os extratos protegidos da luz em presença dos copigmentos apresentaram um aumento do tempo de meia vida: 856,49 $\mathrm{h}$ para o ácido gálico e 923,17 h o ácido fítico enquanto que para o controle foi de 152,67 h. Estes resultados indicam claramente que o manjericão roxo é uma potencial fonte de compostos bioativos estáveis.

Palavras-chave: antocianinas, extração, pigmentos, metodologia de superfície de resposta.

\section{REFERENCES}

Alvarez PA, Emond C, GomaA A, Remondetto GE AND Subirade M. 2015. Predictive response surface model for heatinduced rheological changes and aggregation of whey protein concentrate. J Food Sci 80: 326-333.

AMR A AND AL-TAMIMI E. 2007. Stability of the crude extracts of Ranunculus asiaticus anthocyanins and their use as food colourants. Int J Food Sci Tech 42: 985-991.

AWIKA JM. 2008. Behavior of 3-deoxyanthocyanidins in the presence of phenolic copigments. Food Res Int 41: 532-538.

BĄKOWSKA A, KUCHARSKA AZ AND OSZMIAŃSKI J. 2003. The effects of heating, UV irradiation, and storage on stability of the anthocyanin-polyphenol copigment complex. Food Chem 81: 349-355.

BASSANI DC, NUNES DS AND GRANATO D. 2014. Optimization of phenolics and flavonoids extraction conditions and antioxidant activity of roasted yerba-mate leaves (Ilex paraguariensis A. St.-Hil., Aquifoliaceae) using response surface methodology. An Acad Bras Cienc 86: 923-934.

BETTINI V, FIORI A, MARTINO R, MAYELLARO R AND TON P. 1985. Study of the mechanism whereby anthocyanosides potentiate the effect of catecholamines on coronary vessels. Fitoterapia 54: 67-72.

BRAND-Williams W, CUVELIER ME AND BERSET C. 1995. Use of a free radical method to evaluate antioxidant activity. Lebensm Wiss-Technol 28: 25-30.

BRIDLE P AND TIMBERLAKE CF. 1997. Anthocyanins as natural food colours-selected aspects. Food Chem 58: 103-109.

CAPECKA E, MARECZEK A AND LEJA M. 2005. Antioxidant activity of fresh and dry herbs of some Lamiaceae species. Food Chem 93: 223-226.

CARVAlHo-Filho JLS, Blank AF, Alves PB, Ehlert PBA, MElo AS, CAVAlCANTi SCH, ARRigoni-BlanK MF AND SilvaMANN R. 2006. Influence of the harvesting time, temperature and drying period on basil (Ocimum basilicum L.) essential oil. Rev Bras Farmacogn 16: 24-30.

ESCRIBANO-BAILÓN MT, SANTOS-BUELGA C AND RIVAS-GONZALO JC. 2004. Review-Anthocyanins in cereals. J Chromatogr A 1054: 129-141.

FRANCIS FJ. 1989. Food Colorants: Anthocyanins. Crit Rev Food Sci 28: 273-314.

GAUCHE C, MALAGOLI ES AND LUIZ MTB. 2010. Effect of pH on the copigmentation of anthocyanins from Cabernet Sauvignon grape extracts with organic acids. Sci Agr 67: 41-46.

GRANATO D, CALADO VMA AND JARVIS B. 2014a. Observations on the use of statistical methods in food science and technology. Food Res Int 55: 137-149.

GRANATO D, GREVINK R, ZIELINSKI AAF, NUNES DS AND VAN RUTH SM. 2014b. Analytical strategy coupled with response surface methodology to maximize the extraction of antioxidants from green, yellow, and red teas (Camellia sinensis var sinensis). J Agric Food Chem 62: 10283-10296.

GRIS EF, FERREIRA EA, FALCÃO LD AND BORDIGNON-LUIZ MT. 2007. Caffeic acid copigmentation of anthocyanins from Cabernet Sauvignon grape extracts in model systems. Food Chem 100: 1289-1296.

HEREDIA FJ, FRANCIA-ARICHA EM, RIVAS-GONZALO JC, VICARIO IM AND SANTOS-BUELGA C. 1998. Chromatic chaterization of anthocyanins from red grapes-I. pH effect. Food Chem 63: 491-498.

HOLTON TA AND CORNISH EC. 1995. Genetics and biochemistry of anthocyanin biosynthesis. Plant Cell 7: 1071-1083.

HOU Z, QIN P, ZHANG Y, CUI S AND REN G. 2013. Identification of anthocyanins isolated from black rice (Oryza sativa L.) and their degradation kinetics. Food Res Inter 50: 691-697.

KATSABOXAKIS K, PAPANICOLAOU D AND MELANITOU M. 1998. Stability of pigmented orange anthocyanins in model and real food systems. Ital J Food Sci 10: 17-25.

KIM SJ, KIM JM, SHIM SH AND CHANG HI. 2014. Anthocyanins accelerate the healing of naproxen-induced gastric ulcer in rats by activating antioxidant enzymes via modulation of Nrf2. J Funct Foods 7: 569-579. 
LEE JH, LIM JD AND CHOUnG MG. 2013. Studies on the anthocyanin profile and biological properties from the fruits of Acanthopanax senticosus (Siberian Ginseng). J Funct Foods 5: 380-388.

LEE SJ, UMANO K, SHiBAmoto T AND LEE KG. 2005. Identification of volatile components in basil (Ocimum baslicum L.) and thyme leaves (Thymus vulgaris L.) and their antioxidant properties. Food Chem 91: 131-137.

LEES DH AND FRANCIS FJ. 1972. Standardization of pigment analyses in cranberries. Hortscience 7: 83-84.

LIMA VLAG, MÉLO EA AND LIMA DES. 2005. Efeito da luz e da temperatura de congelamento sobre a estabilidade das antocianinas da pitanga roxa. Ciênc Tecnol Aliment 25: 92-94.

MAZZA G AND BROUILLARD R. 1990. The mechanism of co-pigmentation of anthocyanins in aqueous solutions. Phytochem 29: 1097-1102.

Mourtzinos I, Makris DP, YANnAKopoulou K, KALOGERopoulos N, Michali I AND KarathanOS VT. 2008. Thermal Stability of Anthocyanin Extract of Hibiscus sabdariffa L. in the Presence of $\beta$-Cyclodextrin. J Agric Food Chem 56: 1030310310.

NGUYEN PM, KWEE EM AND NIEMEYER ED. 2010. Potassium rate alters the antioxidante capacity and phenolic concentration of basil (Ocimum basilicum L.) leaves. Food Chem 123: 1235-1241.

NONTASAN S, MOONGNGARM A AND DEESEENTHUM S. 2012. Application of functional colourant prepared from black rice bran in yogurt. APCBEE Procedia 2: 62-67.

NunES CA, ALVARENGA VO, SANT'ANA AS, SANTOS JS AND GRANATO D. 2015. The use of statistical software in food science and technology: Advantages, limitations and misuses. Food Res Int 75: 270-280.

OMBRA MN, FRATIANNI F, GRANESE T, CARDINALE F, COZZOLINO A AND NAZZARO F. 2015. In vitro antioxidant, antimicrobial and anti-proliferative activities of purple potato extracts (Solanum tuberosum cv Vitelotte noire) following simulated gastrointestinal digestion. Nat Prod Res 29: 1087-1091.

O'SheA N, RÖBle C, ARENDT E AND GALlagher E. 2015. Modelling the effects of orange pomace using response surface design for gluten-free bread baking. Food Chem 166: 223-230.

PASCUAL-TERESA S. 2014. Molecular mechanisms involved in the cardiovascular and neuroprotective effects of anthocyanins. Arch Biochem Biophys 559: 68-74.

PATIL G, MADHUSUdHAN MC, BADU BR AND RAGHAVARAO KSMS. 2009. Extraction, dealcoholization and concentration of anthocyanin from red radish. Chem Eng Process 48: 364-369.

PATRAS A, BRUNTON NP, O'DONNELL C AND TIWARI BK. 2010. Effect of thermal processing on anthocyanin stability in foods; mechanisms and kinetics of degradation. Food Sci Technol 21: 3-11.

PEDRO AC, GRANATO D AND ROSSO ND. 2016. Extraction of anthocyanins and polyphenols from black rice (Oryza sativa L.) by modeling and assessing their reversibility and stability. Food Chem 191: 12-20.

PEREIRA-CARo G, WATANABE S, FuJimURA T, YOKOTA T AND ASHIHARA H. 2013. Phytochemical profile of a Japanese blackpurple rice. Food Chem 141: 2821-2827.

PHETPORNPAISAN P, TIPPAYAWAT P, JAY M AND SUTTHANUT K. 2014. A local Thai cultivar glutinous black rice bran: A source of functional compounds in immunomodulation, cell viability and collagen synthesis, and matrix metalloproteinase-2 and -9 inhibition. J Funct Foods 7: 650-661.

PHIPPEN WB AND SIMON JE. 1998. Anthocyanins in Basil (Ocimum basilicum L.). J Agric Food Chem 46: 1734-1738.

REBOUÇAS MC, RODRIGUES MCP AND AFONSO MRA. 2014. Optimization of the acceptance of prebiotic beverage made from cashew nut kernels and passion fruit juice. J Food Sci 7: 1393-1398.

REYES LF AND CISNEROS-ZEVALLOS L. 2007. Degradation kinetics and colour of anthocyanins in aqueous extracts of purple and red-flesh potatoes (Solanum tuberosum L.). Food Chem 100: 885-894.

Rice-Evans CA, Miller NJ AND PAGANGA G. 1996. Structure antioxidant activity relationships and flavonoids and phenolic acids. Free Radical Bio Med 20: 993-956.

Rosas JF, SilVA ACM, ZOGHBI MGB AND ANDRADE EHA. 2004. Comparação dos voláteis das folhas de Ocimum micranthum Willd. obtidos por hidrodestilação e destilação-extração simultânea. Rev Bras Plantas Med 7: 26-29.

SAHA J, DEBNATH M, SAHA A, SHOSH T AND SARKAR PK. 2011. Response surface optimization of extraction of antioxidants from strawberry fruit, and lipid peroxidation inhibitory potential of the fruit extract in cooked chicken patties. J Sci Food Agric 9: 1759-1765.

SHAO Q, HUANG Y, ZHOU A, GUO H, ZHANG A AND WANG Y. 2014. Application of response surface methodology to optimise supercritical carbon dioxide extraction of volatile compounds from Crocus sativus. J Sci Food Agric 94: 1430-1436.

SHAO Y, XU F, SUN X, BAO J AND BETA T. 2014. Identification and quantification of phenolic acids and anthocyanins as antioxidants in bran, embryo and endosperm of white, red and black rice kernels (Oryza sativa L.). J Cereal Sci 59: $211-218$.

Silva GJF, CONSTANT PBL, FigueIREdo RW AND MOURA SM. 2010. Formulação e estabilidade de corantes de antocianinas extraídas das cascas de jabuticaba (Myrciaria ssp.). Alimen Nutr 21: 429-436. 
SINGLETON VL, ORTHOFER R AND LAMUELA-RAVENTOS RM. 1999. Analysis of total phenols and other oxidation substrates and antioxidants by means of Folin-Ciocalteu reagent. Method Enzymol 299: 152-178.

StRaCK D And WraY V. 1989. In: Dey PM and Harborne JB (Eds), Anthocyanins, in Methods in Plant Biochemistry, Academic Press, New York, p. 325.

SZYMANOWSKA U, ZŁOTEK U, KARAŚ M AND BARANIAK B. 2015. Anti-inflammatory and antioxidative activity of anthocyanins from purple basil leaves induced by selected abiotic elicitors. Food Chem 172: 71-77.

UdDIN MDS, SARKER MDZI, FERDOSH S, AKANDA MDJH, EASMIN MSTS, BTSHAMSUdin SH AND YUNUS KB. 2015. Phytosterols and their extraction from various plant matrices using supercritical carbon dioxide: a review. J Sci Food Agric 95: 1385-1393.

USMAN LA, ISMAEEL RO, ZUBAIR MF, SALIU BK, OLAWORE NO AND ELELU N. 2013. Comparative studies of constituents and antibacterial activities of leaf and fruit essential oils of Ocimium basilicum grown in north central Nigeria. Int J Chem Biochem Sci 3: 47-52.

VinCIERI FF, ROMANi A, BALdi A, MulinaCCI N AND ALBERTI MB. 1992. Analysis HPLC of anthocyanins present in fluid extracts from Malva sylvestris L. flowers and leaves. Bull. Liaison-Groupe Polyphenols 16: 339-342.

WATERHOUSE AL. 1995. Wine and heart disease. Chem Ind-London 9: 338-341.

WU XL AND PRIOR RL. 2005. Identification and characterization of anthocyanins by high-performance liquid chromatograpyelectrospray ionization-tandem mass spectrometry in common foods in the United States: Vegetables, nuts, and grains. J Agric Food Chem 53: 3101-3113.

ZAWISTOWSKI J, KOPEC A AND KITTS DD. 2009. Effects of a black rice extract (Oryza sativa L. indica) on cholesterol levels and plasma lipid parameters in Wistar Kyoto rats. J Funct Foods 1: 50-56.

ZHANG Y, KONG L, YIN C, JIANG D, JIANG J, HE J AND XIAO W. 2013. Extraction optimization by response surface methodology, purification and principal antioxidant metabolites of red pigments extracted from bayberry (Myrica rubra) pomace. LWT Food Sci Tech 51: 343-347. 